\title{
Detecting desertification in different years and rainfall regimes by 2D Scatter Plot'
}

\author{
Detecção da desertificação em diferentes anos e regimes pluviométricos com \\ Scatter Plot 2D
}

\author{
Thiago Costa dos Santos ${ }^{2 *}$, Adunias dos Santos Teixeira ${ }^{3}$, Fabrício da Silva Terra ${ }^{4}$, Luis Clenio Jário Moreira \\ and Raul Shiso Toma ${ }^{6}$
}

\begin{abstract}
The desertification process causes soil degradation and a reduction in vegetation. The absence of visualisation techniques and the broad spatial and temporal dimension of the data hampers the identification of desertification and rapid decision-making by multidisciplinary teams. The 2D Scatter Plot is a two-dimensional visual analysis of reflectances in the red $(630-690 \mathrm{~nm})$ and nearinfrared $(760-900 \mathrm{~nm}$ ) bands to visualise the spectral response of the vegetation. The hypothesis of this study is that visualising the reflectances of the vegetation by means of a $2 \mathrm{D}$ scatter plot will allow desertification to be inferred. The aim of this study was to identify desertified areas and characterise the spatial and temporal dynamics of the vegetation and soil during dry (DP) and rainy (RP) periods between 2000 and 2008, using a 2D scatter plot. The 2D scatter plot generated by the Envi ${ }^{\circledR} 4.8$ software and the reflectances in bands 3 and 4 of the TM5 sensor were used within communities in the Irauçuba hub (Ceará, Brazil). The concentration densities of the near-infrared reflectances of the vegetation pixels were observed. Each community presented pixel concentrations with reflectances of less than $0.4(40 \%)$ during each of the periods under evaluation, indicating little vegetation development, with further degradation caused by deforestation, the use of fire and overgrazing. The $2 \mathrm{D}$ scatter plot was able to show vegetation with low reflectance in the near infrared during both dry and rainy periods between 2000 and 2008, thereby inferring the occurrence of desertification.
\end{abstract}

Key words: Albedo. Soil Line. Time Series. Big data.

RESUMO - O processo de desertificação causa redução da vegetação e degradação do solo. A ausência de técnicas de visualização e ampla dimensão espaço - temporal dos dados dificultam a identificação da desertificação e a rápida tomada de decisão por equipes multidisciplinares. O Scatter Plot 2D é uma análise visual e bidimensional das reflectâncias das bandas do vermelho $(630-690 \mathrm{~nm})$ e do infravermelho próximo $(760$ - $900 \mathrm{~nm})$ para visualizar a resposta espectral da vegetação. Nesse sentido, a hipótese deste trabalho é que a visualização das reflectâncias da vegetação através do Scatter Plot 2D permitirá inferir a ocorrência de desertificação. Neste estudo o objetivo foi identificar áreas desertificadas e caracterizar a dinâmica espacial e temporal da vegetação e do solo nos períodos secos (FS) e chuvosos (FC), de 2000 a 2008 usando o Scatter Plot 2D. Foram utilizados o 2D Scatter Plot do Envi® 4.8 e as reflectâncias das bandas 3 e 4 do sensor TM5 em comunidades do núcleo de Irauçuba (Ceará, Brasil). Foram observadas as densidades de concentração das reflectâncias dos pixels de vegetação em relação ao infravermelho próximo. Todas as comunidades em todos os períodos de avaliação apresentaram concentrações de pixels com reflectâncias inferiores a 0,4 (40\%), indicando pouco desenvolvimento da vegetação e posterior degradação, causadas pelo desmatamento, uso do fogo e sobre pastejo. Portanto o Scatter Plot 2D foi capaz de mostrar a vegetação com baixas reflectâncias no infravermelho próximo entre os anos de 2000 a 2008 em épocas secas e chuvosas, permitindo inferir a ocorrência da desertificação.

Palavras-chave: Albedo. Linha de Solo. Séries Temporais. Big data.

DOI: $10.5935 / 1806-6690.20210039$

Editor-in-Article: Profa. Mirian Cristina Gomes Costa - mirian.costa@ufc.br

*Author for correspondence

Received for publication 13/06/2020; approved on 15/12/2020

${ }^{1}$ Trabalho extraído da dissertação do primeiro autor apresentada ao programa de Pós-graduação em Ciência do Solo, Universidade Federal do Ceará/UFC ${ }^{2}$ Departamento de Ciências do Solo, Universidade Federal do Ceará (UFC), Fortaleza-CE, Brasil, thiagoengagronomo@hotmail.com_(ORCID ID $000000016749850 \mathrm{X})$

${ }^{3}$ Departamento de Engenharia Agrícola, Universidade Federal do Ceará (UFC), Fortaleza-CE, Brasil, adunias@ufc.br (ORCID ID 00000002 1480 0944 ) ${ }^{4}$ Departamento de Engenharia Agrícola e Ambiental, Instituto de Ciências Agrárias (ICA), Universidade Federal dos Vales do Jequitinhonha e Mucuri (UFVJM), Unaí-MG, Brasil, fabricio.terra@ufvjm.edu.br (ORCID ID 0000 -0002-8901-7970)

${ }^{5}$ Instituto Federal de Educação, Ciência e Tecnologia do Ceará (IFCE), Limoeiro do Norte-CE, Brasil, cleniojario@gmail.com (ORCID ID 000000019918 9744).

${ }^{6}$ Departamento de Ciências do Solo, Universidade Federal do Ceará (UFC), Fortaleza-CE, Brasil, raulstoma@ufc.br (ORCID ID 000000015585 6832). 


\section{INTRODUCTION}

Desertification is the degradation of areas of arid, semi-arid or dry sub-humid climate, due to climate variation and anthropogenic factors, and affects more than 3 million hectares, with a negative influence on biophysics, food security, socioeconomic stability and sustainable development (LAMQADEM; KNOW; PRADHAN, 2018).

Brazil is a leader in terms of drylands (aridity index <0.65). Low rainfall, high temperatures, low phytomass production, reduced input of plant material to the soil, overgrazing, deforestation and improper soil management have contributed to the desertification of $980,711 \mathrm{~km}^{2}$ in the northeast of the country. In the state of Ceará (CE) alone, $14 \%$ of the area has been affected by desertification (SOUSA et al., 2012; TORRES et al., 2015).

The Irauçuba Centro Norte desertification hub (CE) is one of the most studied in north-eastern Brazil. The causes of degradation are overgrazing and deforestation, recurrent practices in the area, which have led to soil compaction and erosion, and a loss of productive potential (ARAUJO FILHO et al., 2002; FERREIRA et al., 2018).

Methods for monitoring desertification in Brazil are based on a vertical approach, and do not consider temporal, spatial or multidisciplinary factors, making identification and monitoring difficult. The involvement of various professionals to study the topic and the availability of images with better temporal and spatial resolutions have reduced uncertainty when modelling desertification (TOMASELLA et al., 2018).

Remote sensing is suitable for studying desertification due to its low cost and fast image acquisition, multidimensional approach and spatial and temporal evaluations of the Earth's surface that result in more accurate models. The Normalised Difference Vegetation Index (NDVI) is an index for monitoring the vegetation based on the red and near-infrared bands; the interaction of these bands with electromagnetic radiation indicates that the visible red absorbs a large part of the radiation, while in the near-infrared, there are high reflectances (CHEN et al., 2019; YOU, 2017).

The literature includes several indices for monitoring desertification; however, these are based on band arithmetic, and require computational resources and specific knowledge, making preliminary analysis by multidisciplinary teams difficult. Based on this problem, the $2 \mathrm{D}$ scatter plot is a two-dimensional resource for displaying the visible and near-infrared bands that can be used for the spectral characterisation of vegetation and soil in time and space, dispensing with arithmetical operations and allowing a visual interpretation of vegetation dynamics (FLOOD, 2017; ZHANG et al., 2013). Studies in semi-arid areas carried out by Zhang et al. (2019), showed that plotting the red and near-infrared reflectances on a $2 \mathrm{D}$ scatter plot identified that dense vegetation cover has a reflectance greater than 0.40 in the near-infrared, between 0.40 and 0.20 for vegetation in desertified areas, and less than 0.20 for exposed soil. The studies by Zhang et al. (2019), serve as a reference for a visual analysis of the spectral behaviour of vegetation in different years and precipitation regimes, and for inferring the occurrence of desertification.

Based on the hypothesis that displaying vegetation reflectance by means of a 2D scatter plot allows inferences to be made concerning desertification, the aim of this study is to identify the desertified areas of rural communities by analysing near-infrared reflectance, and to characterise the spatial and temporal dynamics of the vegetation and soil during the dry (DP) and rainy (RP) periods between 2000 and 2008, using a 2D scatter plot.

\section{MATERIAL AND METHODS}

\section{Study area}

With an area of 9,579.21 $\mathrm{km}^{2}$, the desertification hub of Irauçuba Centro Norte is located between $3^{\circ} 35^{\prime}$ and $4^{\circ} 44^{\prime}$ $\mathrm{S}$ and $39^{\circ} 38^{\prime}$ and $39^{\circ} 63^{\prime} \mathrm{W}$ (Ceará, Brazil) and includes the districts of Irauçuba, Canindé, Miraíma and Santa Quitéria (SOUSA et al., 2012). To carry out the study, five rural communities from the hub were chosen: Bom Jesus $3^{\circ} 44.871^{\prime} \mathrm{S}$ and $39^{\circ} 56.642^{\prime} \mathrm{W}$ (Irauçuba); Fumo $3^{\circ} 51,186^{\prime}$ $\mathrm{S}$ and $39^{\circ} 51,080^{\prime} \mathrm{O}$ (Irauçuba); Maniçoba $4^{\circ} 7.058^{\prime} \mathrm{S}$ and $40^{\circ}$ 23.089'W (Santa Quitéria), Saco de Boi $4^{\circ} 24.842^{\prime} \mathrm{S}$ and $39^{\circ}$ 47.836' W (Santa Quitéria) and Tiracanga $4^{\circ} 33.725^{\prime} \mathrm{S}$ and $39^{\circ} 8.601$ ' W (Canindé), as shown in Figure 1.

\section{Evaluating desertification using the 2D scatter plot}

TM images from the Landsat 05 satellite were reprojected for zone 24 SOUTH and DATUM WGS - 84 using the Envi ${ }^{\circledR} 4.8$ software and submitted to atmospheric correction using the Envi ${ }^{\circledR} 4.8$ Flaash module (ADLER-GOLDEN et al., 1999). Envi ${ }^{\circledR} 4.8$ 2D Scatter Plot was then used to plot the red reflectance on the $\mathrm{X}$-axis and the near infrared on the Y-axis for each community at the end of the dry (DP) and rainy (RP) seasons from 2000 to 2008. Desertification was identified based on a visual analysis of the distribution patterns of the vegetation pixels, using spectral behaviour in the near-infrared, and quantification of the vegetation cover for these patterns. It was decided that pixels sampled in the vegetation space during the dry and rainy periods that presented a near-infrared reflectance of less than 0.40 would be classified as desertified (ZHANG et al., 2019).

The classification of desertification is based on a series of 2D scatter plot images for the five 
Figure 1 - Location of the rural communities Bom Jesus, Fumo, Maniçoba, Saco de Boi and Tiracanga evaluated in the study (Irauçuba Centro Norte, Ceará, Brazil)

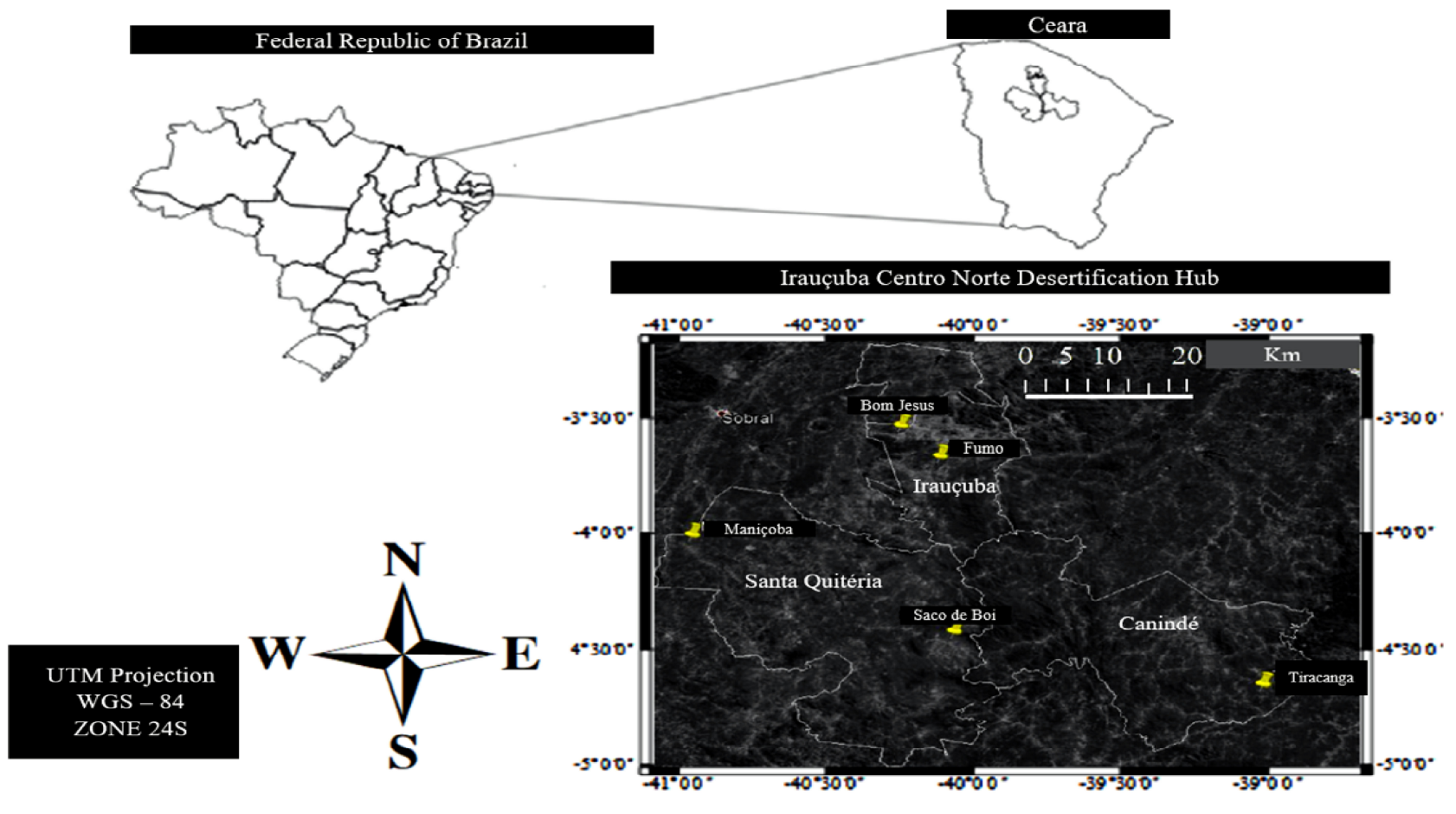

communities between 2000 and 2008 during the dry and rainy seasons. This approach allows the differences between areas affected by drought and desertification to be established with greater certainty, since areas with inadequate vegetation cover due to drought will start the recovery process during the rainy season, unlike desertified areas where, even during the rainy season, the vegetation will not have the same capacity for recovery due to the continuous deterioration of the soil structure and vegetation that result in profound changes to the caatinga biome (SOUZA et al., 2015).

The areas occupied by the vegetation pixels or exposed soil in each scatter plot were plotted on graphs using the Excel software. Reflectance values were on a scale of between 0 and 1 , where values of 0.1 equal a reflectance of $10 \%$.

The results of the 2D Scatter Plot analysis were supported by data from the 2006 and 2010 agricultural and demographic censuses respectively, provided by the Brazilian Institute of Geography and Statistics (IBGE) for the districts in which the areas under study are located. The Mann-Kendall (MK) non-parametric statistical test at 5\% probability, autocorrelation functions (ACF) and the coefficient of variation using the Rstudio software were all applied to verify the existence of trends in the areas of vegetation or exposed soil.

\section{RESULTS AND DISCUSSION}

In general, the 2D scatter plots for each community (Figures 2, 4, 6, 8 and 10) presented vegetation patterns with reduced spectral responses and reflectances of less than $40 \%$ in the near infrared during the dry and rainy periods, indicating poorly developed and stunted vegetation, with an irregular growth pattern and with no capacity for recovery with the rainfall, inferring the occurrence of desertification (ZHANG et al., 2019). The spectral response of the soil in each community presumes the occurrence of impoverished soils, with no organic matter and with a minimal capacity for retaining water and nutrients or offering conditions for the establishment and growth of vegetation.

In the following paragraphs, there are more detailed results and discussions of the spectral response of the vegetation and soil, and the dynamics of the areas of vegetation cover and exposed soil for each of the communities during the dry and rainy periods between 2000 and 2008 .

Analysis of the 2D scatter plot for the community of Bom Jesus indicated that pixels sampled in the vegetation space formed concentrated patterns during the following periods of the years under evaluation: 2000DP, 2001RP, 2004DP, 2004RP, 2005DP, 2005RP, 2006DP, 2006RP, 2007RP, 2008DP and 2008RP. During periods 2000RP and 2003DP, there was a change from concentrated pixel patterns to scattered vegetation pixels (Figure 2). 
Figure 2 - 2D scatter plot of reflectance for vegetation (green) and soil (yellow) in the near infrared (y axis) and visible red (x axis) during the wet (RP) and dry (DP) seasons from 2000 to 2008 in the community of Bom Jesus (Irauçuba, CE)

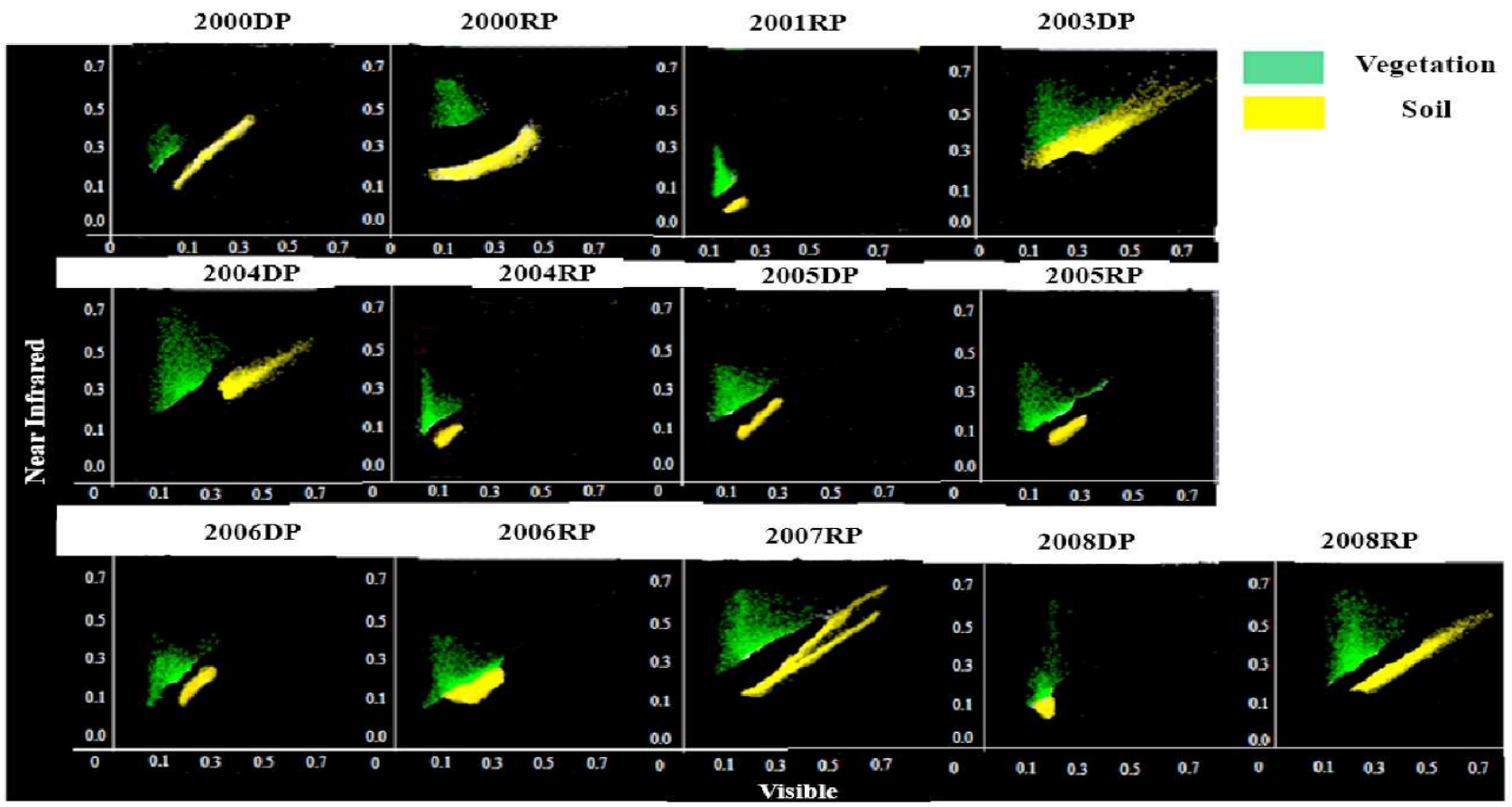

DP: End of dry period; RP: End of wet period

The 2D scatter plot (Figure 2) shows that the vegetation pixels formed patterns which occupied smaller areas on the chart during periods with less vegetation cover. On the other hand, at times of more cover, there was an increase in the areas occupied by vegetation pixels, with the display of concentrated pixel patterns.

The areas of vegetation in the community of Bom Jesus showed less cover during 2001RP, 2004RP, 2006DP and 2008DP, and the most cover during 2004DP, 2007RP, 2008RP and 2005RP. Areas of exposed soil showed an increase during 2004DP, 2005DP and 2006RP. During 2004RP and 2005RP there was a reduction in the area of exposed soil, followed by successive increases from 2006RP to 2008RP, giving a total increase in exposed soil of 1,272.00 $\mathrm{m}^{2}$ between 2006 and 2008. (Figure 3).

From the 2D scatter plot for the community of Fumo, it was found that periods 2001RP, 2004DP, 2005RP, 2006DP, 2006RP, 2007RP and 2008RP showed concentrated patterns of vegetation pixels, unlike 2000DP, 2000RP, 2003DP, 2004RP, 2005DP and 2008DP, where the vegetation pixels were scattered (Figure 4).

The largest areas occupied by the vegetation were seen during 2005DP, 2006RP and 2008RP. Except for 2005DP, the periods were characterised by concentrated patterns of vegetation pixels as shown in Figure 4. The
Figure 3 - Area $\left(\mathrm{m}^{2}\right)$ occupied by vegetation and exposed soil in the community of Bom Jesus (Irauçuba, CE) from 2000 to 2008, during the dry (DP) and rainy (RP) seasons

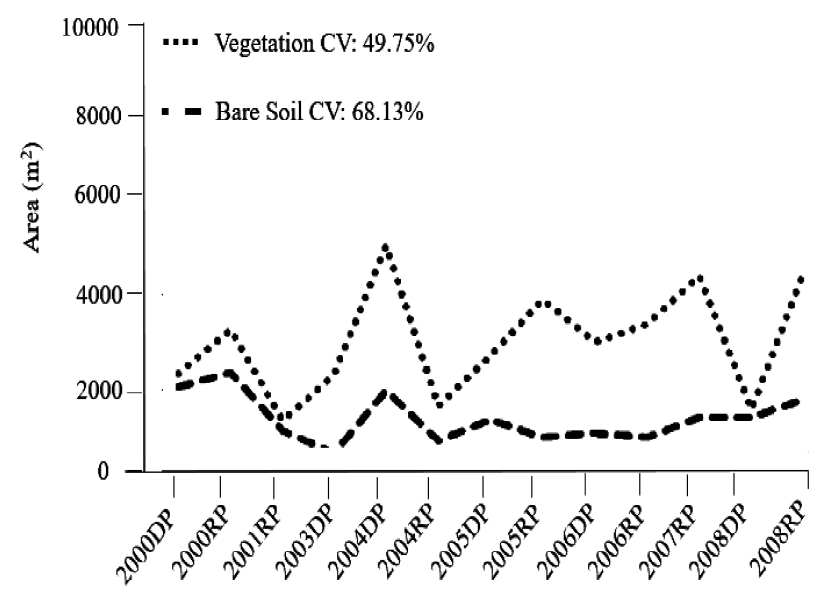

DP: End of dry period; RP: End of wet period; CV: Variation of Coefficient

areas of exposed soil were larger during 2000RP and 2003DP, with a drop in 2001RP and 2004DP, after which the areas of exposed soil again increased (Figure 5). 
Figure 4 - 2D scatter plot of reflectance for vegetation (green) and soil (yellow) in the near infrared (y axis) and visible red (x axis) during the wet (RP) and dry (DP) seasons from 2000 to 2008 in the community of Fumo (Irauçuba, CE)

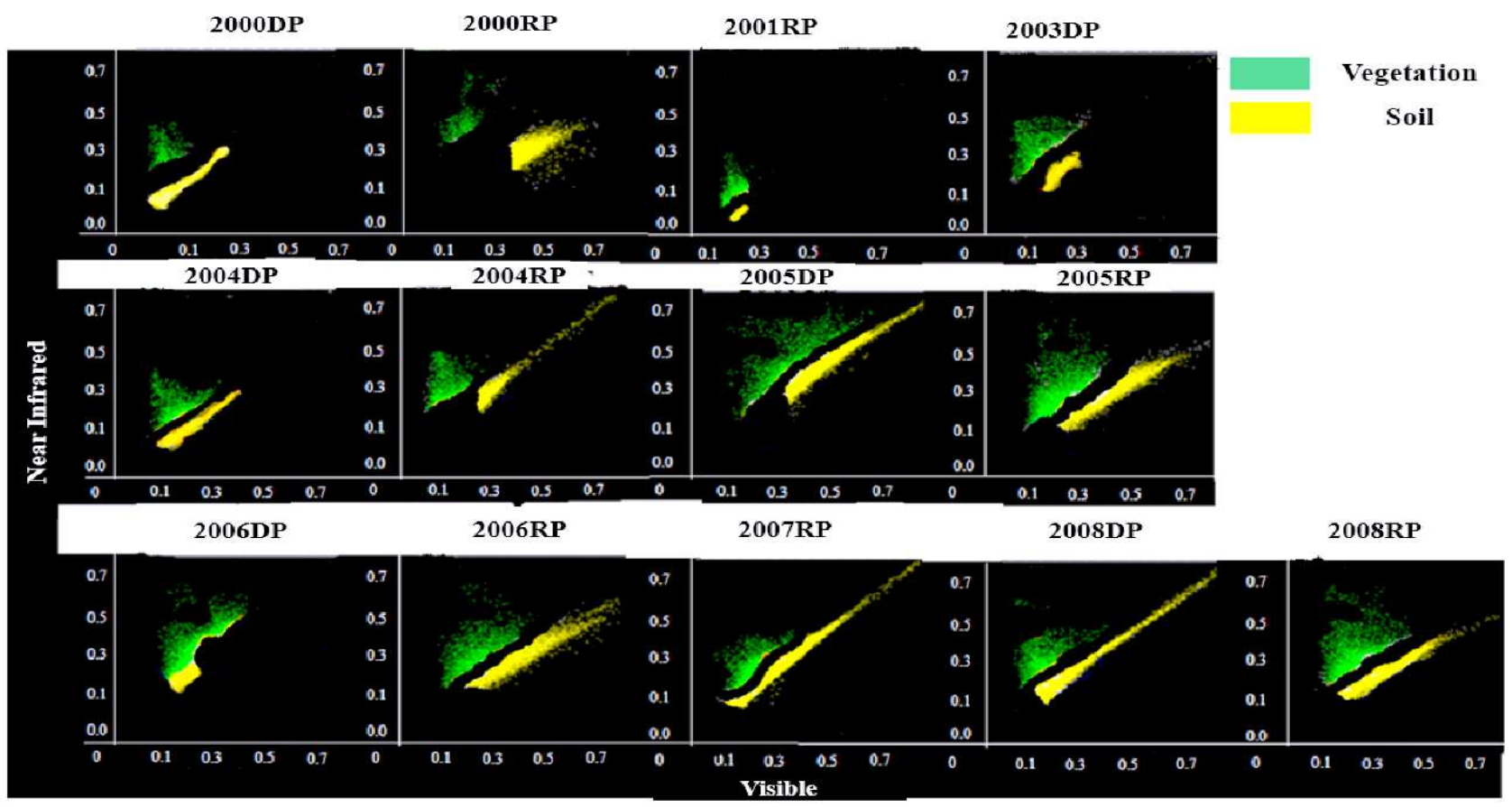

DP: End of dry period; RP: End of wet period

Figure 5 - Area $\left(\mathrm{m}^{2}\right)$ occupied by vegetation and exposed soil in the community of Fumo (Irauçuba, CE) from 2000 to 2008, during the dry (DP) and rainy (RP) seasons

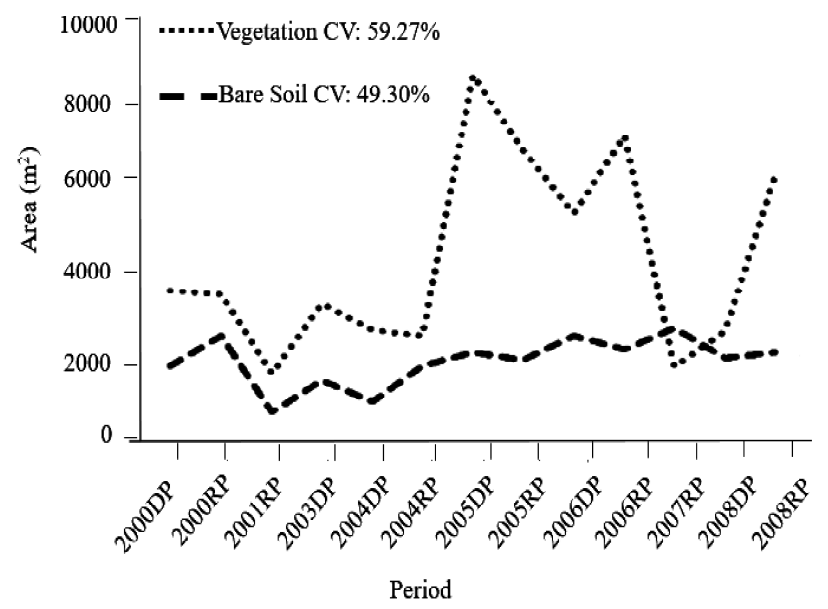

DP: End of dry period; RP: End of wet period; CV: Variation of Coefficient

Analysis of the spectral behaviour of the vegetation in the communities of Fumo and Bom Jesus showed that for each period under study the vegetation pixels presented nearinfrared reflectance patterns below 0.4 , inferring the existence of semi-arid vegetation with little capacity for recovery during rainy periods, a characteristic compatible with desertified areas
(ZHANG et al., 2019). The little and inadequate vegetation cover found by the low spectral response in the near infrared led to the emergence of areas of exposed soil, intensifying erosion, the removal of organic matter and nutrient elements, and contributing to the formation of impoverished soils with little input of plant material, explaining the pattern of spectral behaviour shown by the soil of these communities, in which there is an increase in reflectance in the visible and nearinfrared bands (Figures 2 and 4).

Both communities are located in the district of Irauçuba which, according to Araujo Filho et al. (2002) and Ferreira et al. (2018), presents livestock farming with a greater number of animals than the carrying capacity, and where land-use pressure increased between 2000 and 2006 by $69 \%$ (INSTITUTO BRASILEIRO DE GEOGRAFIA E STATÍSTICA, 2006). This explains the critical situation of overgrazing in the region, which, together with other factors of recurrent degradation in these areas, justifies the results found in this study for the communities of Bom Jesus and Fumo.

The 2D scatter plot for the community of Tiracanga showed that periods 2000DP, 2001RP, 2004DP, 2004RP, 2005DP, 2005RP, 2006DP, 2006RP, 2007RP, 2008DP and 2008RP showed concentrated patterns of vegetation pixels, while during 2003DP the vegetation pixels in the scatter plot were more dispersed (Figure 6). The presence of concentrated pixel patterns indicates vegetation with a 
spectral response of less than 0.40 reflectance in the near infrared during rainy periods, underlining the inability of the vegetation to recover, and presuming desertification. The scattered patterns (2003DP) indicate intense reductions in the area of vegetation for Tiracanga (Figures 6 and 7).

The areas of vegetation cover in the community of Tiracanga were larger during 2001RP, 2003DP, 2004RP and 2007RP, and smaller during 2004DP, 2005DP and 2008RP (Figure 7). During periods of greater vegetation cover the pixels were arranged in patterns concentrated at the bottom of the vegetation space. The areas of exposed soil were larger from 2003DP to 2004RP and during 2007RP (Figure 7).

In Tiracanga, Canindé, a peak in the area of exposed soil was seen in 2007 (Figure 7). During this period, $108,752 \mathrm{~m}^{3}$ of firewood was extracted from the area, which is considered the second district in Ceará in extracted volume, second only to Santa Quitéria. Analysis of historical data from the IBGE showed that in $2004101,986 \mathrm{~m}^{3}$ were extracted, $103,515 \mathrm{~m}^{3}$ in 2005 , and $106,620 \mathrm{~m}^{3}$ in 2006 (INSTITUTO BRASILEIRO DE GEOGRAFIA E STATÍSTICA, 2010), which favoured desertification, since exposure of the soil intensified the erosion process and other factors of soil and plant degradation. These factors acted continuously over the years, resulting in the formation of vegetation with reflectance patterns below 0.40 in the near infrared, with less capacity to respond to rainy periods and, therefore, classified as desertified (CUNHA et al., 2019; LANDIM; SILVA; ALMEIDA, 2011; OLIVEIRA FILHO et al., 2019).

From 2004RP onwards, there is a reduction in the spectral response of the vegetation, indicating loss of the capacity for recovery during rainy periods, with the pixel pattern always concentrated below a reflectance of 0.4 in the near infrared, showing little vegetation cover. On the other hand, the spectral response of the soil always indicates increasing reflectance in the visible and near infrared, denoting the presence of exposed and depleted soils with little organic matter content due to the amount of deforestation that reduces the input of plant material to the soil and increases the loss of nutrients and soil structure, reducing the capacity to sustain vegetation.

From the 2D scatter plot for the community of Maniçoba, the vegetation pixels were found to be concentrated during all periods, i.e. well grouped within the vegetation space, an indication that even during rainy periods the vegetation of the Maniçoba community showed no changes in spectral response pattern (Figure 8).

The largest areas of vegetation cover in Maniçoba were seen during 2000RP, 2004RP and 2007RP, with reductions during 2003DP, 2004DP, 2006DP and 2008DP (Figure 9).

Figure 6 - 2D scatter plot of reflectance for vegetation (green) and soil (yellow) in the near infrared (y axis) and visible red (x axis) during the wet (RP) and dry (DP) seasons from 2000 to 2008 in the community of Tiracanga (Canindé, CE)

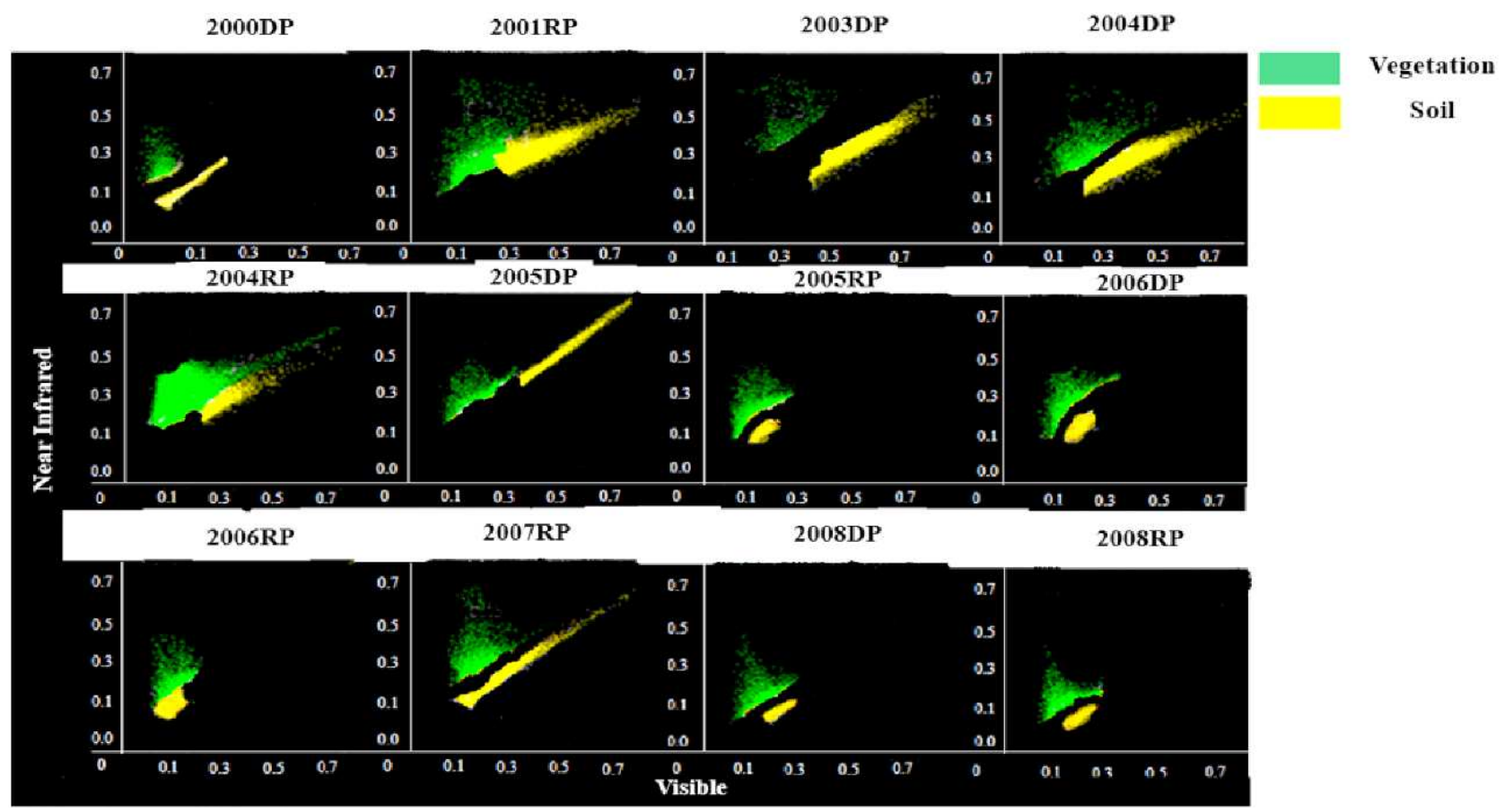

DP: End of dry period; RP: End of wet period 
Peaks in the areas of exposed soil were seen during 2000RP, 2004RP, 2005RP and 2006RP, followed by a reduction until 2008RP. From 2004RP to 2006RP the areas of exposed soil oscillated around higher mean values $\left(2077.10 \mathrm{~m}^{2}\right)$ compared to the other periods. At the end of 2006RP there was a reduction in the areas of exposed soil, and between 2001RP and 2004DP there were no sudden changes (Figure 9).

Figure 7 - Area $\left(\mathrm{m}^{2}\right)$ occupied by vegetation and exposed soil in the community of Tiracanga (Canindé, CE) from 2000 to 2008, during the dry (DP) and rainy (RP) seasons

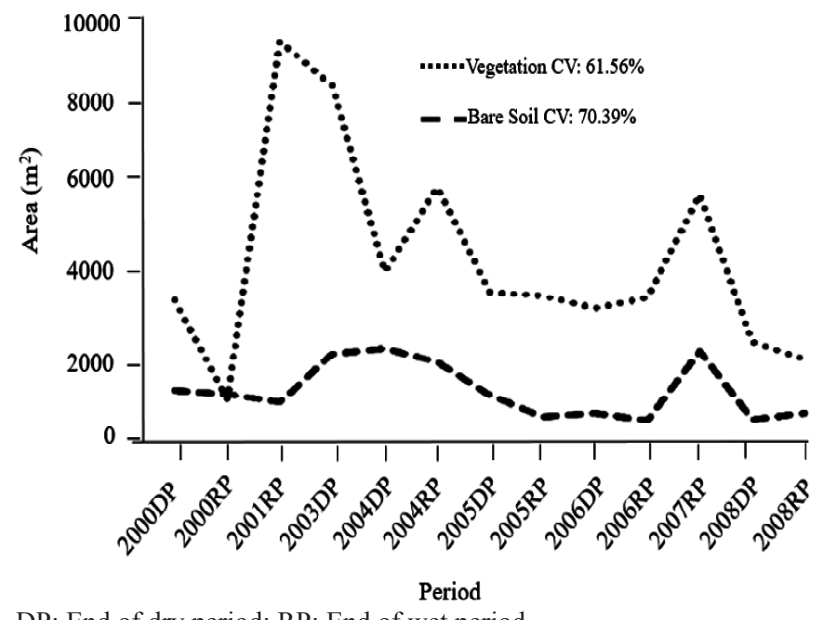

DP: End of dry period; RP: End of wet period
The 2D scatter plot for the community of Saco de Boi in Santa Quitéria (CE) showed that periods 2000RP, 2001RP, 2004DP, 2004RP, 2006DP, 2006RP, 2007RP, 2008DP and 2008RP presented vegetation pixels with concentrated patterns, while during 2000DP, 2003DP and 2005DP the vegetation pixels were dispersed (Figure 10).

There were larger areas of vegetation during 2003DP, 2005DP and 2006DP, while there was an increase in exposed soil from 2001RP and a reduction during 2007RP, followed by an increase during 2008DP with a drop during 2008RP (Figure 11).

The 2D scatter plots for the communities of Saco de Boi and Maniçoba located in the district of Santa Quitéria presented vegetation showing spectral behaviour compatible with desertified areas. This may be related to the recurrent practices of burning and deforestation in Santa Quitéria favouring the extractive removal of firewood. Cross-checking the peaks in the areas of exposed soil in the communities of Santa Quiteria (Figures 9 and 11) with deforestation data provided by the Brazilian Institute of Geography and Statistics (2010) showed that the years with the largest areas of exposed soil were 2004, 2006 and 2008, during which $131,531 \mathrm{~m}^{3}, 137,537 \mathrm{~m}^{3}$ and $141,970 \mathrm{~m}^{3}$ of wood were removed respectively.

Figure 8 - 2D scatter plot of reflectance for vegetation (green) and soil (yellow) in the near infrared (y axis) and visible red (x axis) during the wet (RP) and dry (DP) seasons from 2000 to 2008 in the community of Maniçoba (Santa Quitéria, CE)

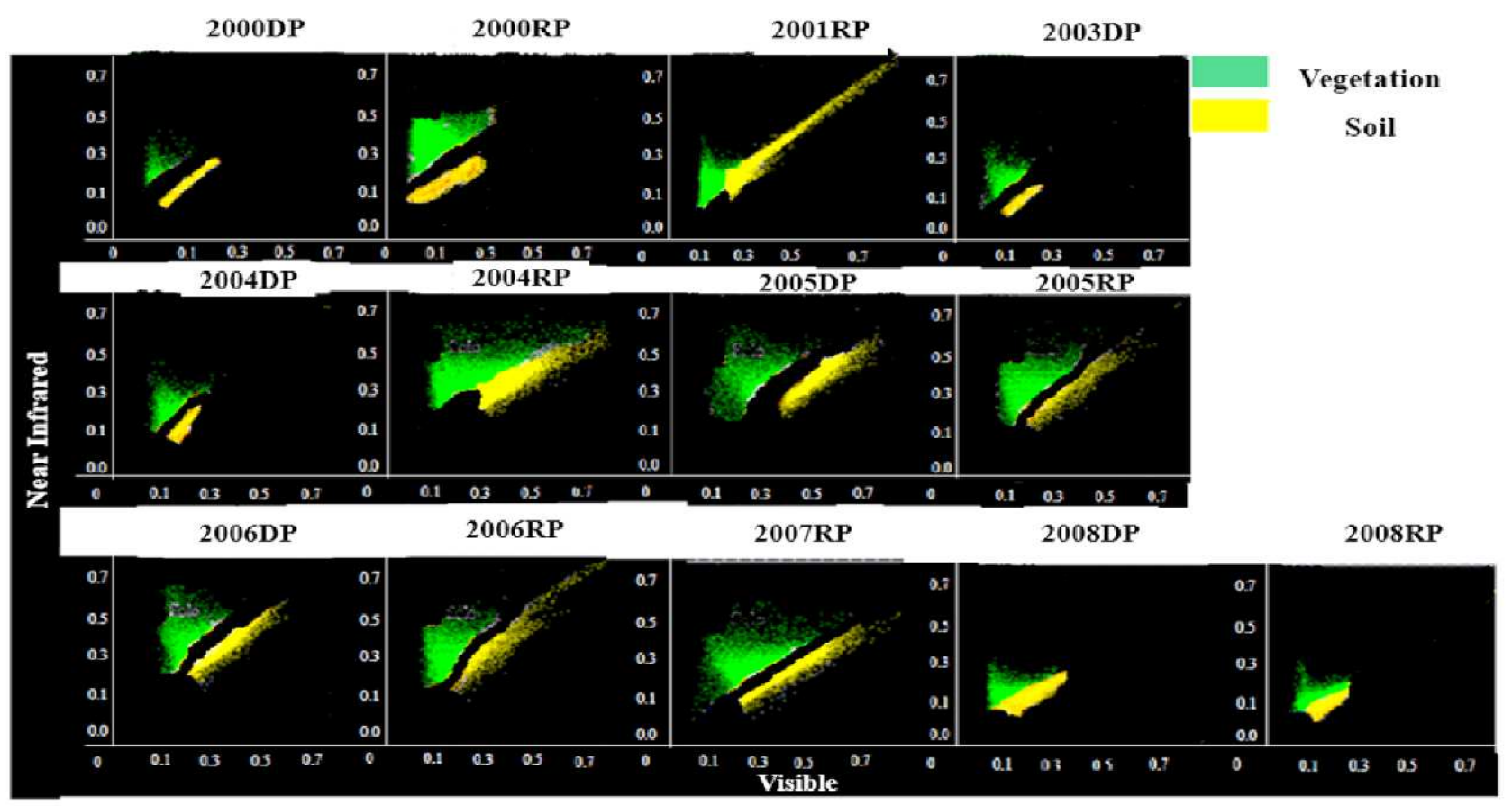

DP: End of dry period; RP: End of wet period 
Santa Quiteria was ranked in 2007 as the largest extractor of vegetation for firewood production in the state of Ceará (INSTITUTO BRASILEIRO DE GEOGRAFIA E STATÍSTICA, 2010), resulting in changes in the growth pattern of the Caatinga. This can be identified by the spectral response pattern of the vegetation in the Saco de Boi and Maniçoba communities always displaying pixels

Figure 9 - Area $\left(\mathrm{m}^{2}\right)$ occupied by vegetation and exposed soil in the community of Maniçoba (Santa Quitéria, CE) from 2000 to 2008, during the dry (DP) and rainy (RP) seasons

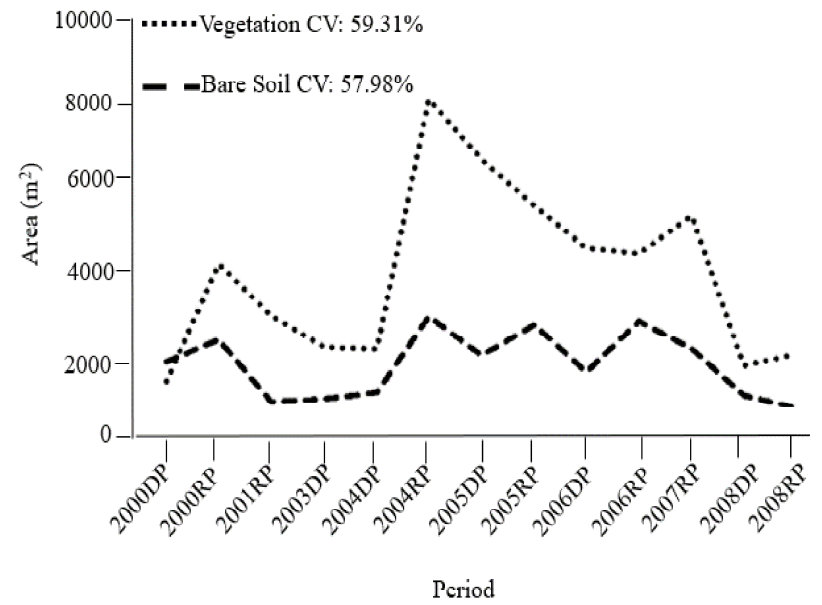

DP: End of dry period; RP: End of wet period with a reflectance of less than 0.40 in the near-infrared, leading to the appearance of exposed soil and the start of soil depletion, helping to increase reflectance in the visible and near-infrared, and reducing the capacity of the soil to provide the conditions for plant growth.

The reflectance patterns of the vegetation in these communities are due to misuse and occupation of the soil, the practices of burning, overgrazing and deforestation, and the great dependence of the local population on the biome for survival. These aspects have helped to deplete the soil, fauna and flora, triggering the formation of vegetation in degraded semi-arid areas under stress with limited conditions for development, reflecting in changes in the optical properties of the leaf mesophyll and a reduction in the reflectance of the cellular structure (BAIG et al., 2014; BEURS; OWSLEY; JULIAN, 2016; ROMAN; URSU, 2016; ZHANG et al., 2019).

An analysis of the time series for vegetation and exposed areas of soil showed neither trend, seasonality or stationarity, indicating that the areas of vegetation and exposed soil between 2000 and 2008 were quite heterogeneous in relation to their mean values $(\mathrm{CV}>30 \%$ and $\mathrm{ACF}=0)$. This proves the influence of random factors on the time series, i.e. irregular variations in vegetation cover and exposed areas of soil occurred due to unexpected events such as burning and deforestation (SILVA et al., 2018).

Figure 10 - 2D scatter plot of reflectance for vegetation (green) and soil (yellow) in the near infrared (y axis) and visible red (x axis) during the wet (FC) and dry (FS) seasons from 2000 to 2008 in the community of Saco de Boi (Santa Quiteria, CE)

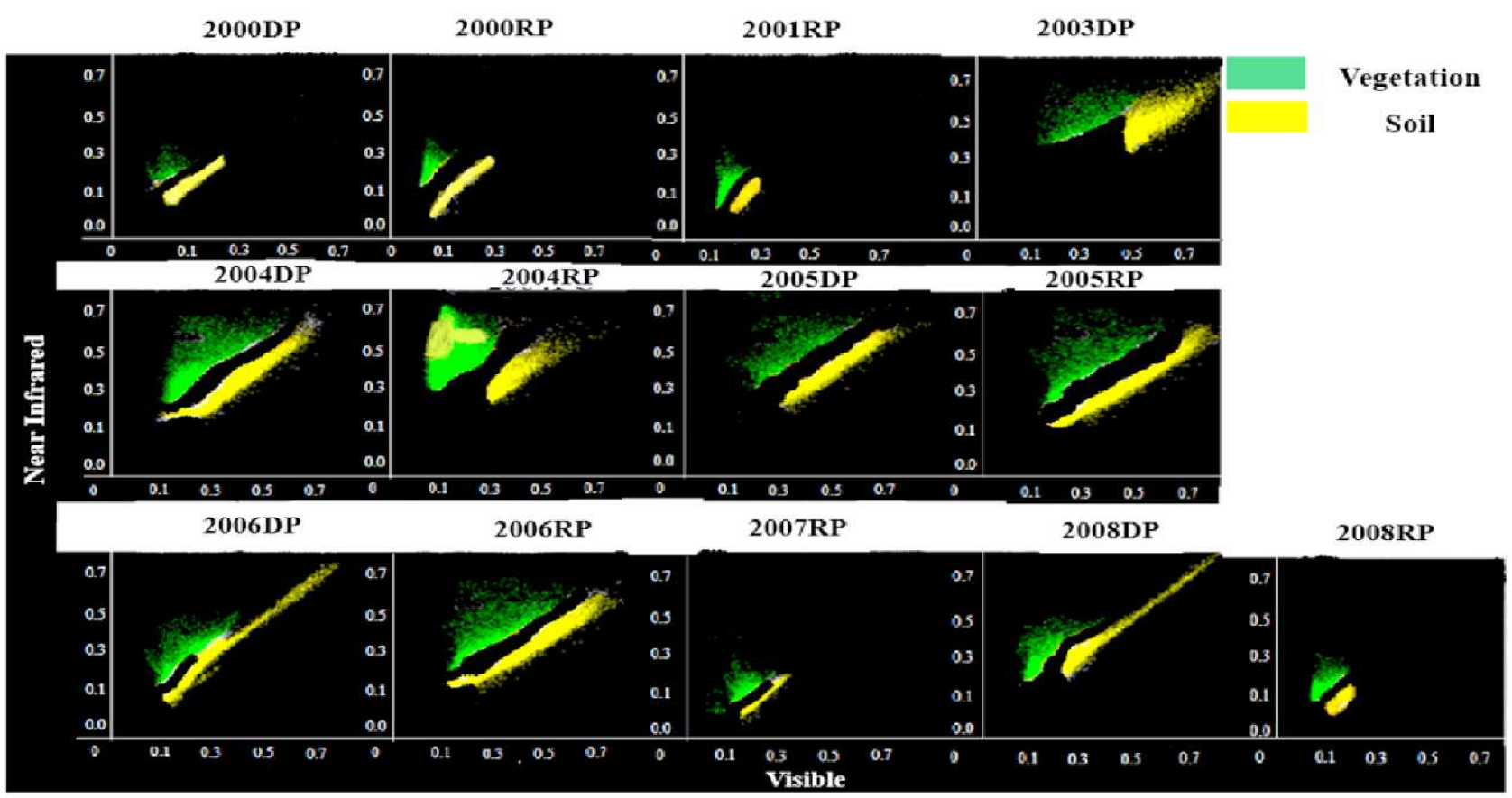

DP: End of dry period; RP: End of wet period 
Figure 11 - Area $\left(\mathrm{m}^{2}\right)$ occupied by vegetation and exposed soil in the community of Saco de Boi (Santa Quitéria, CE) from 2000 to 2008, during the dry (DP) and rainy (RP) seasons

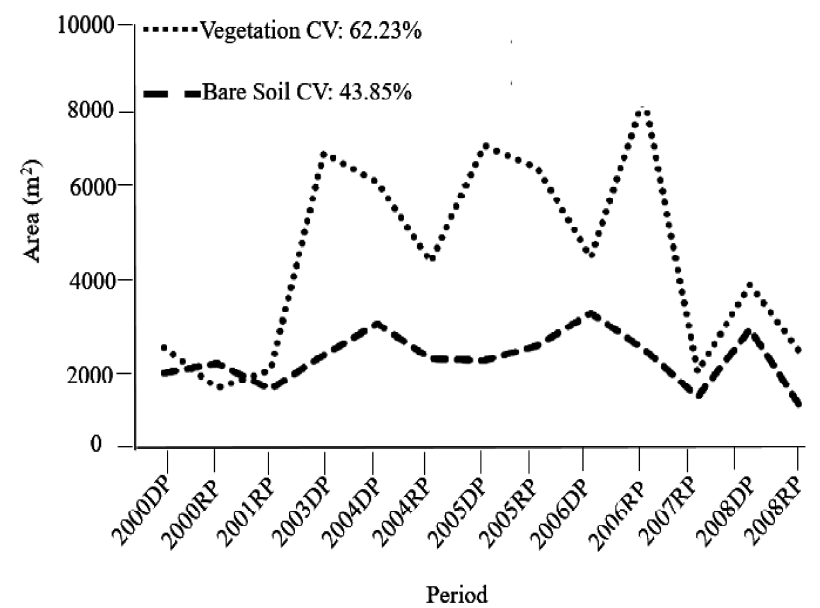

DP: End of dry period; RP: End of wet period; CV: Variation of Coefficient

\section{CONCLUSIONS}

1. Displaying vegetation reflectance using the $2 \mathrm{D}$ scatter plot for different years and rainfall regimes identified desertification in each of the communities under study;

2. Each community presented vegetation with reflectance patterns in the near-infrared compatible with those of semi-arid areas under desertification. The spatial and temporal dynamics of the areas of vegetation and exposed soil during dry and rainy periods presume low resilience for these areas due to deforestation and overgrazing, contributing to desertification;

3. The 2D scatter plot showed great potential for visualising vegetation reflectance over the years under study, dispensing with the use of algebraic operations and the processing of large databases, and can be used by multidisciplinary teams involved in studying the behaviour of vegetation and predicting desertification.

\section{ACKNOWLEDGEMENTS}

The authors would like to thank the Coordenação de Aperfeiçoamento de Pessoal de Nível Superior (CAPES) and the Grupo de Automação em Manejo Agrícola - Desenvolvimento Tecnológico (GAMA DT) for providing intellectual and financial support, and Pro-Integração for the project resources.

\section{REFERENCES}

ADLER-GOLDEN, S. M. et al. A revanche dos ventos. Ciência \& Ambiente, v. 1, p. 7-31, 1999.

ARAÚJO FILHO, J. A. et al. Desempenho produtivo de ovinos da raça morada nova em caatinga raleada sob três taxas de lotação. Revista Ciência Agronômica, v. 33, p. 51-57, 2002.

BAIG, M. H. A. et al. Derivation of a tasselled cap transformation based on Landsat 8 at-satellite reflectance. Remote Sensing Letters, v. 5, p. 423-431, 2014.

BEURS, K. M.; OWSLEY, B. C.; JULIAN, J. P. Disturbance analyses of forests and grasslands with MODIS and Landsat in New Zealand. International Journal of Applied Earth Observation and Geoinformation, v. 45, p. 42-54, 2016.

CHEN, Y. et al. Remote sensing for vegetation monitoring in carbon capture storage regions: a review. Applied Energy, v. 240, p. 312-326, 2019 .

CUNHA, J. E. B. et al. Surface albedo as a proxy for landcover clearing in seasonally dry forests: evidence from the Brazilian Caatinga. Remote Sensing of Environment, v. 231, p. 111-250, 2019.

FERREIRA, M. P. S. et al. Changes in attributes of soils subjected to fallow in desertification hotspot. Revista Ciência Agronômica, v. 49, p. 22-31, 2018.

FLOOD, N. Comparing Sentinel-2A and Landsat 7 and 8 using surface reflectance over Australia. Remote Sensing, v. 9 , p. $2-14,2017$.

INSTITUTOBRASILEIRODEGEOGRAFIAEESTATÍSTICA. Censo Agropecuário 2006. Disponível em: www.ibge.gov.br/ estatisticas/economicas/agricultura-e-pecuaria/9105-producaoda-extracao-vegetal-e-da-silvicultura.html?t=downloads. Acesso em: 12 jan. 2017.

INSTITUTOBRASILEIRODEGEOGRAFIAEESTATÍSTICA. Censo demográfico 2010. Disponível em: www.ibge.gov.br/ estatisticas/economicas/agricultura-e-pecuaria/9105-producaoda-extracao-vegetal-e-da-silvicultura.html?t=downloads. Acesso em: 12 jan. 2017.

LAMQADEM, A.; SABER, H.; PRADHAN, B. Quantitative assessment of desertification in an arid oasis using remote sensing data and spectral index techniques. Remote Sensing, v. 10, p. 1-18, 2018.

LANDIM, R. B. T. V.; SILVA, D. F.; ALMEIDA, H. R. R. C. Desertificação em Irauçuba (CE): investigação de possíveis causas climáticas e antrópicas. Revista Brasileira de Geografia Física, v. 1, p. 1-21, 2011.

OLIVEIRA FILHO, J. S. et al. Assessing the effects of 17 years of grazing exclusion in degraded semi-arid soils: evaluation of soil fertility, nutrients pools and stoichiometry. Journal of Arid Environments, v. 166, p. 1-10, 2019.

ROMAN,A.;URSU,T.Multispectralsatelliteimageryandairborne laser scanning techniques for the detection of archaeological vegetation marks. In: OPREANU, C. H.; LĂZĂRESCU, V.-A. (ed.) Landscape archaeology on the northern frontier of the roman 
empire at porolissum: an interdisciplinary research project. ClujNapoca: Mega Publishing House, 2016. p. 141- 152.

SILVA, C. R. et al. Analysis of the phenology dynamics of brazilian caatinga species with ndvi time series. Cerne, v. 24, p. 48-58, 2018.

SOUSA, F. P. et al. Carbon and nitrogen in degraded Brazilian semi-arid soils undergoing desertification. Agriculture, Ecosystems \& Environment, v. 148, p. 11-21, 2012.

SOUZA, B. I. et al. The Caatinga and desertification. Mercator, v. 14, p. 131-150, 2015.

TOMASELLA, J. et al. Desertification trends in the Northeast of Brazil over the period 2000-2016. International Journal of Applied Earth Observation And Geoinformation, v. 73, p. 197-206, 2018.
TORRES, L. et al. Desertification Research in Argentina. Land Degradation \& Development, v. 26, p. 433-440, 2015.

YOU, H. Orienting rocky desertification towards sustainable land use: na advanced remote sensing tool to guide the conservation policy. Land Use Policy, v. 61, p. 171-184, 2017.

ZHANG, J. et al. A new remote sensing dryness index based on the near-infrared and red spectral Space. Remote Sensing, v. 11, p. $2-28,2019$.

ZHANG, Y. et al. Type classification of 2D scatter plot of remote sensing image based on the physical meaning and extraction of remote sensing alteration information. Remote Sensing for Land \& Resources, v. 25, p. 57-62, 2013. 